\title{
Comparative study between semi-intensive and scavenging production system on the performances of Black Bengal goat
}

\author{
M. R. Islam, M. R. Amin, A. K. M. A. Kabir and M. U. Ahmed \\ Department of Animal Science, Bangladesh Agricultural University, Mymensingh-2202, Bangladesh
}

\begin{abstract}
The experiment was aimed to investigate and compare the growth, milk production and reproductive performances of Black Bengal goat under semi-intensive production (IP) and scavenging production (SP) system. Six Black Bengal does were assigned into 2 treatment (IP and SP) having 3 in each group. The IP group was allowed to graze six hours daily and supplemented with concentrate (soybean meal and wheat bran) and roughage (sorghum and common grass) and the SP group was maintained by the rural landless farmer traditionally as scavenging system. The average birth weight of kids were 1.30 and $0.96 \mathrm{~kg}$ for IP and SP systems, respectively and varied significantly $(P<0.01)$. The birth weight of male kids were significantly $(P<0.01)$ higher than that of the female kids. Pre-weaning gain was also significantly $(P<0.01)$ higher in IP than $\mathrm{sp}$ system. In both the systems, male kids always showed higher gain than that of females. The kids were weaned at an average age of 92 and 81 days for IP and SP systems, respectively. The kids of the IP and SP systems attained at an average weaning weight of 5.43 and $4.17 \mathrm{~kg}$, respectively which differs significantly $(P<0.01)$. Weaning weight was found to be significantly higher in IP than SP systems. Average initial live weight, live weight at kidding and final live weight at post partum heat of does of IP and SP systems were 22.10, 22.61 and 21.03 and $21.90,22.35$ and $19.73 \mathrm{~kg}$, respectively, where there was no significant difference except the final live weight $(\mathrm{P}<0.05)$. The average daily milk yield, total lactation yield and lactation length for IP and SP systems were 214 $\mathrm{ml}, 20.47 \mathrm{I}$ and 95.33 days and $162 \mathrm{ml}, 13.75 \mathrm{I}$ and 84.66 days, respectively and varied significantly $(P<0.01)$. Average litter size of the IP and SP systems was 2.00 and 2.33, respectively. Average post partum heat period and kid mortality were significantly $(P<0.01)$ lower in IP than SP system. Gross return was found higher in IP than that of SP systems. Thus, it can be recommended from the present study that the growth rate, weaning age, weaning weight, milk production, post partum heat period and kid mortality of Black Bengal goat could be improved through proper feeding and better husbandry system which was reflected from gross return.
\end{abstract}

Keywords: Semi-intensive, Scavenging, Production, Reproduction, Black Bengal goat

\section{Introduction}

The tropical and subtropical climate in association with topography provides a unique habitat for goats. The conductive climate, dense vegetation and rural socio-economic structure facilitated concentration of goat population in these regions. Land scarcity, severe unemployment and extreme poverty of the underprivileged group of people compel them towards production of low cost generating animal like goat. More than $95 \%$ goats are being kept by the farmers living in the rural areas and goat keeping becomes an accessory source of income to the landless peasants in the rural community in Bangladesh (Amin, 2000). Many of the landless and marginal farmers own 1-5 goats and contribute economically to the subsistence farmers in mixed farming systems (Husain, 1993).

There are about 300 breeds and varieties of goats domesticated in this subcontinent. Indian subcontinent has the largest (31.4\%) goat population next to Africa (41.3\%). In Bangladesh, it constitutes about $7 \%$ of the total Asiatic goat population which accounted for 20.75 millions heads (DLS, 2007). The goat ranks second position in terms of meat and skin production, representing about 38 and 28 percent, respectively, of the total livestock in Bangladesh (FAO, 2003). The breed is early maturing with first kidding occurring at about 8-12 months. The goat is important for its adaptability, fertility, prolificacy, delicious meat, and skin softness. The Black Bengal goat is a good meat producing animal but it produces very little milk usually $250 \mathrm{ml}$ per day. In Bangladesh, goat produces about 130000 and 1312000 MT meat and milk, respectively per year (FAO, 2004). These poor productions of both milk and meat are due to their poor genetic makeup and improper nutrition and management. The interaction of genetics and nutrition is important and nutrition does not increase the production beyond the genetic potentialities but can help to express the maximum potentiality. The nutritional status and management system of Black Bengal goat is very poor due to shortage of feeds and fodder both in quality and quantity. Goats are generally reared as scavengers by the rural farmer in Bangladesh (Huq, 1990). The poor farmers mainly keep goats in semi-intensive production system 
without any supplementation. This system of production causes reduced growth and poor reproductive performance, which in turn, results severe economic losses. The genetic potentiality and productivity of these goats are deteriorating day by day due to indiscriminate breeding, lack of improved feeding and management practices. In many tropical countries, the productivity of goats is often poor and has been related to disease, nutrition, genotypes and management (Devendra and Burns, 1983). Studies conducted by various authors reflected the facts that grazing alone may not be sufficient for optimum live weight gain and reproductive performance of goats. Therefore, if traditional system can be improved with better feeding and management, the level of production can be increased with minimum investment. Keeping this view in mind, the present study was therefore undertaken to investigate and compare some productive and reproductive performances of Black Bengal goats under improved and traditional management system to exploit the potentialities of goats for the welfare of the rural poor and village community.

\section{Materials and Methods}

\section{Selection of does, housing and management}

The experiment was conducted at the Goat and Sheep farm and the laboratory of Animal Science under the Department of Animal Science, Bangladesh Agricultural University and also in a village of Boyra Union adjacent to Bangladesh Agricultural University campus. The experiment was carried out for a period of 6 months. Six advanced pregnant (3 months) Black Bengal does were selected for the study and were divided into two treatments as semi-intensive production (IP) and scavenging production (SP) system having three in each group. IP group was reared with improved feeding and management in the Goat and Sheep farm of Bangladesh Agricultural University and the SP group was reared with scavenging system by the landless farmers in the village of Boyra, Mymensingh. Selected does were kept in three separate pens with an area of $1.5 \mathrm{sq}$ meters. Separate feeders were used for roughage and concentrate feeding. Fresh drinking water was made available in bucket at all the times.

\section{Feeding system and Plan of nutrition}

The does were allowed 15 days to adapt to the experimental conditions prior to the commencement of the study. The dams were allowed flushing for 1 month after adjustment period. IP group were supplied required amount of chopped sorghum and natural grasses twice a day. Concentrate feeds (wheat bran, Soybean meal), Calcium oxide and Common salt were also given twice daily, once in the morning at $7.00 \mathrm{am}$ and in the afternoon at $4.00 \mathrm{pm}$. IP does were allowed for grazing and exercise for a specific period of 6 hours daily. On the other hand, SP does were grazed naturally and residual rice and tree leaves were supplied occasionally. Extra care was not taken for SP does.

\section{Parameters considered}

Productive parameters: The initial weight of all experimental does were taken at the beginning of the experiment and the body weight of all does were taken once in a week during the experimental period and recorded to observe the live weight changes of does. The weight was taken in the morning at 7.00 before feeding. The body weight of does was also measured after kidding. The birth weight of newborn kids was taken within one hour after birth and the subsequent weight of kids were recorded on each successive weekend up to 3 months. Weaning weight of kids were considered as the final weight for kids and the birth weight of kids were subtracted from final body weight to calculate the weight gain of each kid. Kid mortality was recorded after kidding till weaning. The quantity of milk was estimated by milking the does once in a week starting from $7^{\text {th }}$ day of kidding. Milking was done in the morning and evening and the average milk yield ( $\mathrm{ml} / \mathrm{day}$ ) was calculated and recorded for each doe.

Reproductive Parameters: Litter size was calculated as the number of kids born per kidding per doe. The days at which the does showed their heat was recorded properly and post partum heat period (PPHP) was calculated from the time interval after kidding to the subsequent heat. 
Economic study: Cost benefit analysis was calculated by comparing the total cost (Purchase cost of does, feeds, labour, etc.) and the return from IP and SP systems and the gross return was calculated by the differences between the systems.

Statistical analysis: All the data obtained from the experiment were analyzed with the help of Paired Sample Test (t-test) using Statistical Package for Social Science (SPSS 11.5, SPSS Inc. 1999, Microsoft Corporation, 1998 windows package).

\section{Results and Discussion}

\section{Productive Performances}

\section{Performances of kid}

Birth weight, weaning weight and age, pre weaning weight gain, daily growth, rate and mortality rate are considered for comparative evaluation of the performances of kids in two different management systems.

Birth weight: The birth weight of male and female kids for two different systems are presented in Table 1. The kids of IP were significantly $(P<0.01)$ heavier than the kids of SP system. The mean birth weight of IP kids was 35\% higher than kids of SP system. Mia et al. (1993) demonstrated higher birth weight of Black Bengal kids $(1.35 \mathrm{~kg}$ ) which was found to be almost similar to IP but $40 \%$ higher than SP kids in the present findings. Acharya (1987) in his study reported that season of the year, type of birth, parity, age and weight of dam at kidding are the factors which significantly affect the birth weight. Variation in birth weight is partly genetic but largely due to environment especially nutrition, management and health (Devendra and Burns, 1983). Dam's weight is also related to birth weight of kids. This may be due to favourable maternal environment as evidenced by the higher body weight at kidding reported by Prasad et al. (1972) and Khan (1980) in Barbari and Jamnapari breeds, respectively. The higher birth weight of kids may also be due to the size and weight of dam and buck used at the time of mating. Higher birth weight in IP system of the present findings possible due to higher nutrition might ensure subsequent better embryonic development during the pregnancy period.

\section{Table 1. Performances of kids in IP and SP systems}

\begin{tabular}{|c|c|c|c|c|}
\hline \multirow{2}{*}{ Traits } & \multirow{2}{*}{ Sex } & \multicolumn{2}{|c|}{ System } & \multirow{2}{*}{$\begin{array}{l}\text { Level of } \\
\text { significance }\end{array}$} \\
\hline & & IP & SP & \\
\hline \multirow{3}{*}{ Birth weight $(\mathrm{kg})$} & $M$ & $1.38 \pm 0.01$ & $1.03 \pm 0.03$ & ** \\
\hline & $\mathrm{F}$ & $1.23 \pm 0.01$ & $0.90 \pm 0.02$ & ** \\
\hline & $\mathrm{M}+\mathrm{F}$ & $1.30 \pm 0.03$ & $0.96 \pm 0.03$ & ** \\
\hline \multirow{3}{*}{ Weaning weight (kg) } & $\mathrm{M}$ & $5.55 \pm 0.05$ & $4.27 \pm 0.01$ & ** \\
\hline & $\mathrm{F}$ & $5.31 \pm 0.07$ & $4.06 \pm 0.03$ & * \\
\hline & $\mathrm{M}+\mathrm{F}$ & $5.43 \pm 0.05$ & $4.17 \pm 0.03$ & ** \\
\hline \multirow{3}{*}{ Pre-weaning gain $(\mathrm{kg})$} & $\mathrm{M}$ & $4.16 \pm 0.06$ & $3.20 \pm 0.02$ & ** \\
\hline & $\mathrm{F}$ & $4.08 \pm 0.06$ & $3.16 \pm 0.01$ & ** \\
\hline & $\mathrm{M}+\mathrm{F}$ & $4.12 \pm 0.05$ & $3.17 \pm 0.01$ & ** \\
\hline \multirow[t]{3}{*}{ Body weight gain per day (g) } & $\mathrm{M}$ & $46.33 \pm 0.37$ & $36.00 \pm 0.22$ & ** \\
\hline & $\mathrm{F}$ & $45.33 \pm 0.29$ & $35.11 \pm 0.15$ & ** \\
\hline & $\mathrm{M}+\mathrm{F}$ & $45.83 \pm 0.47$ & $35.59 \pm 0.22$ & ** \\
\hline Weaning age $(d)$ & $\mathrm{M}+\mathrm{F}$ & $92.00 \pm 1.52$ & $81.00 \pm 1.00$ & * \\
\hline Kid mortality (\%) up to weaning & $M+F$ & 0 & 14.28 & ** \\
\hline
\end{tabular}

* = Significant at $\mathrm{P}<0.05$, ** $=$ Significant at $\mathrm{P}<0.01, \mathrm{M}=$ Male, $\mathrm{F}=$ Female

$\mathrm{IP}=$ Semi-intensive production, $\mathrm{SP}=$ Scavenging production 
Growth rate and pre weaning gain: The growth rate and pre weaning gain of kids in two different systems are presented in Table 1 . Growth rate was significantly $(P<0.01)$ higher in the IP than in SP systems. Saadullah (1991) and Khan and Singh (1989) found that the daily body weight gain in Black Bengal goat from birth to three months was $51.87 \mathrm{~g}$ which was slightly higher than the present findings. Provision of improved feeding system during late pregnancy and lactation period may increase the growth performance of kids. The average growth rate in pre weaning period was slightly higher in males than females. Similar result was reported in male kids of Thai native goats which is $20 \%$ higher than female kids (Pralomkarn et al., 1996). Pre weaning gain was found significantly higher $(P<0.01)$ in IP than SP system. Yusuff et al. (1981) reported that the season of the year and sex type has significant effect on pre weaning average daily gain. In the present study, it was observed that pre weaning gain was higher in the IP system and weight gain of male kids was always higher than females. Higher nutrition supplied to dams of IP system increased milk production, thus improve the body condition score of kids may be the cause of higher pre weaning gain in the IP system.

Weaning weight and age: The weaning age and weaning weight of two different systems are presented in Table 1. The kids of the IP reached at weaning age 11 days later than the SP system and the difference was significant $(P<0.05)$. The higher values for weaning weight in both sexes were observed in IP than SP system. The kids of IP achieved 30\% heavier weaning weight than SP system. Manir (2006) reported that weaning weight of Black Bengal kids was $4.02 \mathrm{~kg}$ which is lower than the present study. Weaning weight of kids is influenced by breed, birth weight and lactation performances of dam, weaning age, pre-weaning nutrition and litter size. Sex type has significant effect on weaning weight and male kids were slightly heavier than females at weaning in the IP system but significantly heavier than females in the SP system. Similar observation was reported by Ozekin and Akcapinar (1983). Singh et al. (1991) reported that weaning age of Black Bengal goat was three months which is in agreement with the present findings. Longer weaning age of the IP system might be due of longer lactation length of the dams.

Kid mortality: The kid mortality up to weaning in two different systems is shown in Table 1 . The mortality rate was observed $15 \%$ in SP but there was no mortality in the IP system. High mortality of kids is a major cause of economic loss. This result was partially supported by Chowdhury et al. (2002), who found that the average mortality rate was $8 \%$ in Black Bengal goat. Husain (1999) found the average mortality rate of Black Bengal goat maintained by farmers were $5-12 \%$ which is similar to the present findings. The higher kid mortality in the SP system was probably due to traditional management which in turn causes lower milk production of dam. Kid mortality is responsible with many factors such as effect of dam weight at kidding, effect of birth weight of kid, dam's milk yield, season, litter size, parity, dam's nutrition and disease (Chowdhury et al., 2002).

\section{Performances of dam}

Live weight changes of dam: The live weight changes of does in IP and SP systems during the experimental period are presented in Table 2. The live weight at kidding was tented to be higher in IP system but the difference was not significant. There was no significant difference between IP and SP system in terms of fortnightly live weight changes before kidding. Loss of live weight just after kidding is higher in IP system but not differed significantly. The fortnightly live weight changes was found significantly $(P<0.01)$ higher in IP than SP system. Loss of live weight just after kidding was 10 percent higher in IP group than SP system. The result was almost similar with Sarker (2006). It may be due to the higher birth weight of kids born in IP group. Calhoun et al. (1988) reported that increasing energy intake have a positive effect on live weight changes of goats. This result was similar with the present findings. In another study Shahjalal et al. (1997) also found increased growth rate of Black Bengal goats by supplying increased protein supplementation. 
Daily milk production: The milk yield per day in IP and SP systems are presented in Table 3. Daily milk yield per day was observed significantly higher $(P<0.01)$ in the IP than SP system. This result was comparable with Alam (1992) who reported the milk yield of Black Bengal goat under village condition was $200 \mathrm{ml} /$ day. Higher correlation $(r=0.80-0.90)$ between milk production and net energy intake during the lactation of goat was reported by Flamant and Morand-Fehr (1982). It can be speculated that improved management and higher supply of protein and energy through feed could ensure more milk production per day than traditional management system. Breed, birth type, age, parity and interaction between nutrition and environment effect milk production.

Table 2. Body weight changes of dam in IP and SP system

\begin{tabular}{|l|c|c|c|}
\hline Parameter & IP & SP & $\begin{array}{c}\text { Level of } \\
\text { significance }\end{array}$ \\
\hline Initial live weight $(\mathrm{kg})$ & $22.10 \pm 0.11$ & $21.90 \pm 0.15$ & NS \\
\hline Live weight at kidding $(\mathrm{kg})$ & $22.61 \pm 0.07$ & $22.35 \pm 0.18$ & $\mathrm{NS}$ \\
\hline Fortnightly live weight changes before kidding $(\mathrm{kg})$ & 0.51 & 0.45 & $\mathrm{NS}$ \\
\hline Live weight just after kidding (kg) & $19.60 \pm 0.02$ & $19.63 \pm 0.20$ & $\mathrm{NS}$ \\
\hline Loss of live weight just after kidding (kg) & 3.01 & 2.71 & $\mathrm{NS}$ \\
\hline Fortnightly live weight changes after kidding $(\mathrm{kg})$ & $0.23 \pm 0.007$ & $0.016 \pm 0.02$ & $* *$ \\
\hline Average final live weight $(\mathrm{kg})$ at PPHP & $21.03 \pm 0.06$ & $19.73 \pm 0.23$ & $*$ \\
\hline
\end{tabular}

* = Significant at $\mathrm{P}<0.05,{ }^{*}=$ Significant at $\mathrm{P}<0.01, \mathrm{NS}=$ Not significant, $\mathrm{IP}=$ Semi-intensive production, $\mathrm{SP}=$ Scavenging production, $\mathrm{PPHP}=$ Post partum heat period

Table 3. Milk production performances of dam in IP and SP system

\begin{tabular}{|l|c|c|c|}
\hline Parameter & IP & SP & Level of significance \\
\hline Daily milk yield $(\mathrm{ml})$ & $214+0.001$ & $162+0.003$ & ${ }^{\star *}$ \\
\hline Lactation period (day) & $95.33+1.45$ & $84.66+1.45$ & ${ }^{\star *}$ \\
\hline Total lactation yield $(\mathrm{I})$ & $20.47+0.44$ & $13.75+0.41$ & ${ }^{\star \star}$ \\
\hline
\end{tabular}

** = Significant at $\mathrm{P}<0.01, \mathrm{IP}=$ Semi-intensive production, $\mathrm{SP}=$ Scavenging production

Lactation length: The lactation length of does in two different systems is presented in Table 3 . The lactation length of IP was found 10 days higher than SP system and the difference was significant $(P<0.01)$. The result of the present study is in accordance with Husain (1999), who reported that lactation length of Black Bengal goats was 98-105 days under rural scavenging condition. In a study, Akhter et al. (2006) observed lactation length of Black Bengal goat was 92 days which is similar to the lactation length of IP system and the lactation length of SP system is close to the findings of Chowdhury et al. (2002) who observed the average lactation length of Black Bengal goats at first, second and third parity was 72,82 and 81 days, respectively. This variation is mainly due to genetic and non-genetic factors especially genetic ability of the dams, nutrition and management.

Total lactation yield: Total lactation yield of does in two different systems is present in Table 3. Total lactation yield differed significantly $(p<0.01)$ between IP and SP systems. The does of IP produced $48.87 \%$ higher milk in a lactation period than that of SP system. The yield per lactation of the present findings is similar with those reported by Chowdhury et al. (2002). Lactation yield was positively correlated with the nutrition, age, genotype and season as suggested by Chowdhury et al. (2002) and Mia et al. (1993). Differences in management and nutritional status of the does might be responsible for variation in total lactation yield in this study. Poor nutrition in late pregnancy in addition to reduced weight and vigour of kids at birth can delay the onset of lactation. Moreover, consumption of milk by kids during lactation in SP system may influence total yield of milk. 


\section{Reproductive performances of dam}

Litter size: The average litter size of does of IP and SP systems are presented in Table 4. The higher litter size (2.33) was observed in SP and it was $16.50 \%$ larger than IP group although the variation was not significant.

Table 4. Reproductive performances of does in IP and SP system

\begin{tabular}{|l|c|c|c|}
\hline Parameter & IP & SP & Level of significance \\
\hline Post partum heat period (day) & $77.00 \pm 4.04$ & $95.33 \pm 2.60$ & ** \\
\hline Litter size & $2.00 \pm 0.00$ & $2.33 \pm 0.33$ & NS \\
\hline
\end{tabular}

** $=$ Significant at $\mathrm{P}<0.01, \mathrm{NS}=$ Not significant

$\mathrm{IP}=$ Semi-intensive production, $\mathrm{SP}=$ Scavenging production

In the present study, the litter size of IP (2.0) was slightly lower than SP system (2.33), the result is almost similar with 2.15 and 1.93, reported by Amin et al. (2001) and Husain (1993), respectively for Black Bengal goat but higher than 1.70 (Mia, 1992). Litter size was affected by parity, age, genetic and environmental factors (Chowdhury et al., 2002; Amoah and Gelaye, 1990) and also by buck that is used for mating purpose (Verma et al., 1991).

Post partum heat period: Post partum heat period of does in two different production systems are present in Table 4. The higher PPHP was observed in SP than IP system and was varied significantly $(P<0.01)$. Does of IP exhibited PPHP 18 days earlier than SP system. In the present findings, PPHP was similar to that reported by Husain (1993). PPHP ranged between 16-136 days in Black Bengal does observed by Hossain (2003). The present observation was found within the range. PPHP in Black Bengal goat was 61 days reported by Devendra and Burns (1983) which is lower than the present findings. The present results indicated that environmental factors such as feeding, housing and reproductive management system may influence PPHP. In the present study, 18 days longer PPHP noticed in the SP system was probably due to improper heat detection, reproductive disorder, under nutrition, inefficient and insufficient management and sickness of the does. Apparently better nutrition and management was probably the most important contributory factor responsible for lowering the PPHP in this experiment.

From the findings of the present study, it can be concluded that low milk yield of does, grow rate and weaning weight of kids in Black Bengal goat under traditional management system can be improved by feeding supplementation rich in protein, carbohydrate and minerals and by better husbandry practices.

Table 5. Cost and return of IP and SP system

\begin{tabular}{|l|r|r|}
\hline Parameters & IP & SP \\
\hline Purchase cost (Tk.) & 4500 & 4450 \\
\hline Feed cost (Tk.) & 1426 & 300 \\
\hline Labour cost (Tk.) & 600 & 600 \\
\hline Housing cost (Tk.) & 200 & - \\
\hline Medication cost (Tk.) & 100 & $\mathbf{5 4 1 0}$ \\
\hline \hline Total cost (Tk.) & $\mathbf{6 8 2 6}$ & 4350 \\
\hline Return from doe $(n=3)$ & 5500 & 2300 \\
\hline Return from kids $(n=6)$ & 3600 & 30 \\
\hline Return from faeces (Tk.) & 60 & $\mathbf{6 6 5 0}$ \\
\hline \hline Total return (Tk.) & $\mathbf{9 1 6 0}$ & $\mathbf{1 2 4 0}$ \\
\hline \hline Gross return (Tk.) & $\mathbf{2 3 3 4}$ & \\
\hline \hline
\end{tabular}

Gross return $=$ Total return - Total cost

$\mathrm{IP}=$ Semi-intensive production, $\mathrm{SP}=$ Scavenging production 


\section{Cost benefit study}

The cost benefit was calculated by subtracting the total cost from total return and presented in Table 5. The gross return was found TK 1094 higher in the IP than SP group. In a study, Chelapandiah and Balachandraw (2003) reported that supplementation of concentrate resulted higher weight gain in Black Bengal kids and reduces the cost of production. It could be assumed from the present study that better feeding with improved management might be beneficial and profitable for the goat keepers.

\section{Conclusion}

It can be concluded from the present findings that improved feeding with better management may ensure higher productive and reproductive performances of Black Bengal goats and are profitable for goat rearing in Bangladesh.

\section{References}

Acharya, R. M. 1987. Breeds of goats and research programme for their improvement in India. Proceedings of the IV International Conference on Goats. Held on March 8-13 in Brasilia, Brazil, 1: 772-805.

Akhter, S., Husain, S. S., Chowdhury, S. A., Munzur, M. M. and Dev, G. K. 2006. Estimation of variance components and prediction of breeding value for some economically important traits of Black Bengal goat. Bangladesh Journal of Animal Science, 35: 20-26.

Alam, M. R. 1992. Research and goat production system in Bangladesh. Proceeding of the $V$ International Conference on Recent Advances in Goat Production. Held on March 2-8, 1992 in New Delhi, India, 1: 4.

Amin, M. R. 2000. Genetic Improvement of Production Traits in Bangladesh Goats by Selective Breeding and Crossbreeding. Ph. D. Thesis, Department of Animal Breeding and Genetics, Bangladesh Agricultural University, Mymensingh.

Amin, M. R., Husain, S. S. and Islam, A. B. M. M. 2001. Reproductive peculiarities and litter weight in different genetic groups of Black Bengal does. Asian-Australasian Journal of Animal Science, 14(3): 297-301

Amoach, E. A. and Gelaye, S. 1990. Reproductive performance of female goat in South Pacific countries. Small Ruminant Research, 3: 257-267.

Calhoun, M. C., Lupton, C. J., Kuhlmann, S. W. and Baldwin, J. B. C. 1988. Dietary energy intake and effect on mohair growth. Texas Agricultural Station, Progress Report, pp. 45-49.

Chelapandiah, M. and Balachandraw, S. 2003. Effect of concentrate supplementation on the body weight gain of range managed kids. Indian Journal of Small Ruminants, 9(1):71-72.

Chowdhury, S. A., Bhuiyan, M. S. A. and Faruque, S. 2002. Rearing Black Bengal goat under Semi-intensive management. I. Physiological and Reproductive Performances. Asian-Australisian Journal of Animal Science, 15(4): 477-484.

Devendra, C. and Burns, M. 1983. Goat production in the Tropics. Commonwealth Agricultural Bureax, Farnham House, Farham Royal, Slough, SL2 3BN, United Kingdoms.

DLS. 2007. Department of Livestock Services, Ministry of Fisheries \& Livestock Government of the Peoples Republic of Bangladesh.

FAO. 2003. Food and Agriculture Organization of the United Nations Production Year Book, Rome, Italy, 57.

FAO. 2004. Food and Agriculture Organization of the United Nations Production Year Book, Rome, Italy, 58.

Flamant, J. C. and Morand-Fehr, P. 1982. Milk production in sheep and goat. World Animal science production system approach, I. E. Coop (editor). pp. 275-293.

Hossain, S. M. J. 2003. Study on performance and milk production performance of Black Bengal goat under semi-intensive management. M. S. Thesis, Department of Animal Science, Bangladesh Agricultural University, Mymensingh, pp. 2140.

Huq, M. A. 1990. Evaluation of the meat production characteristics of Black Bengal goats under control and field condition. Ph. D. Thesis, Department of Animal Science, Bangladesh Agricultural University, Mymensingh, Bangladesh.

Husain, S. S. 1993. A study on the productive performance and genetic potentials of Black Bengal goats. Ph. D. Thesis, Department of Animal Breeding and Genetics, Bangladesh Agricultural University, Mymensingh, pp. 3-108.

Husain, S. S. 1999. Sustainable genetic improvement of economic traits of Black Bengal goats through selective and crossbreeding. Bangladesh Agricultural University Research Progress, 10: 72-80.

Khan, A. A. and Singh, D. K. 1989. Annual progress report. All Indian coordinated research project on goats for meat production. Birsa Agricultural University, Ranchi, Bihar, India (30-137). 
Khan, B. U. 1980. Studies on the variation in body weights due to non-genetic factors in Jamnapari goats. Presented at First Annual Symposium of the Indian Society of Animal Genetics and Breeding on "Genetics and Livestock Development" held at Ajmer, 1-3 February, 1980.

Manir, H. M. 2006. Studies on the performance of Black Bengal, Jamnapari goats and their $F_{1}$ crosses at Government Goat Development Farm in Savar. M.S. Thesis, Department of Animal Science, Bangladesh Agricultural University, Mymensingh.

Mia, M. M. 1992. A comparative study on the performance of Black Bengal, Barbari, Anglo Nubian and Black Bengal $x$ Barbari goats. M. Sc. Thesis, Department of Animal Breeding and Genetics, Bangladesh Agricultural University, Mymensingh, p. 29.

Mia, M. M., Ali, A. and Howlider, M. A. R. 1993. Growth performance of Black Bengal, Barbari x Black Bengal goat. Indian Journal of Animal Science, 63(11): 1214-1215.

Ozekin, N. C. and Akcapinar, H. 1983. Some factors affecting growth in Angora kids. Ankara Universities Veterinary Fakultesi Dergisi. 30(22): 317-327. (From Animal Breeding Abstract, 52(11): 6669.

Prasad, S. P., Roy, A. and Pandey, M. D. 1972. Live weights, growth in Barbari kids up to one year of age. Agra University Journal Research (Science), 20: 45-54.

Pralomkarn, W., Saithenoo, S., Mgampongsai, W., Suwanrut, C. and Milton, J.T.B. 1996. Growth and puberty traits of Thai native (TN) and TN $\times$ Anglo-Nubian does. Asian-Australasian Journal of Animal Sciences, 9(5): 591-595.

Saadullah, M. 1991. Research and development activities and needs on small ruminants in Bangladesh. In: Research and Development Needs of Small Ruminants in Asia. Small Ruminant Production Systems Network in Asia (SRUPNA). Andi Djajianegara and C. Devendra (Editor). Indonesia.

Sarkar, M. M. 2006. Effect of urea molasses block on the performance of Black Goat. MS Thesis, Development of Animal Science, Bangladesh Agricultural University, Mymensingh, pp. 19-20.

Shahjalal, M., Biswas, M. A. A. and Tareque, A. M. M. 1997. Effect of feeding sesbania leaves on growth and nutrient utilization in goats. Bangladesh Journal of Animal Science, 26(1-2): 117-123.

Singh, D. K., Singh, C. S. P. and Mishra, H. R. 1991. Genetic and non-genetic factors affecting post-weaning survivability in goats. Animal Production, 53(2): 199-202.

SPSS. Windows for version-11.5. Release on 27.10.1999 (Microsoft Crop. 1998). Trends SPSS Inc., Michigan Avenue, Chicago, IL. 19-182.

Verma, R. R. P., Singh, B. K., Singh, M. P. and Singh, B. 1991. Factors affecting reproductive performance in Black Bengal goats. Indian Veterinary Journal, 68(1): 235-239.

Yusuff, M. K., Sulaiman, A. W. and Ohtman, A. S. H. 1981. Comparative pre-weaning growth performance of crossbred kids. Malaysian Veterinary Journal, 7(2): 29-36. 